\title{
Foraging and provisioning strategies of the light-mantled sooty albatross at South Georgia: competition and co-existence with sympatric pelagic predators
}

\author{
R. A. Phillips* ${ }^{*}$ J. R. D. Silk, J. P. Croxall \\ British Antarctic Survey, Natural Environment Research Council, High Cross, Madingley Road, Cambridge CB3 0ET, UK
}

\begin{abstract}
Foraging and provisioning strategies of the light-mantled sooty albatross (LMSA) Phoebetria palpebrata were studied during chick-rearing at Bird Island, South Georgia, in January to May 2003. Virtually all trips of satellite-tracked birds were restricted to Antarctic waters. Individual birds followed a diversity of foraging routes, the majority to shelf and shelf-slope areas along the southern Scotia Arc or to oceanic waters in the mid Scotia Sea, with only a few trips extending as far south as the marginal ice zone in the Weddell Sea. Sympatric white-chinned petrels Procellaria aequinoctialis, black-browed Thalassarche melanophrys and grey-headed albatrosses T. chrysostoma also exploit these areas. Unlike LMSA, these species and the wandering albatross Diomedea exulans, also forage on the shelf and shelf-slope waters surrounding South Georgia, or at the Antarctic Polar Front (APF), where the larger albatrosses and smaller, more manoeuvrable white-chinned petrel may out-compete LMSA for access to prey. As a consequence, foraging distances and maximum ranges are greater, chick-feeding frequencies are lower and chick growth rate is slower in LMSA than in sympatric Thalassarche albatrosses, and adult LMSA appear to have little capacity to regulate provisioning according to chick condition. Nonetheless, LMSA seem well-adapted to exploitation of distant foraging grounds, apparently using the wind to reduce flight costs and, in comparison with other albatrosses, spending more of the night on the wing and returning with food loads that represent a greater proportion of adult mass.
\end{abstract}

KEY WORDS: Activity pattern $\cdot$ Competition $\cdot$ Niche specialisation $\cdot$ Provisioning rate $\cdot$ Spatial segregation

\section{INTRODUCTION}

Early studies of niche partitioning in seabirds concentrated on north temperate and tropical communities (Ashmole \& Ashmole 1967, Pearson 1968, Cody 1973, Bédard 1976). These suggested a variety of mechanisms, including differences in timing of breeding, diet and foraging habitat, which might limit the intensity of inter-specific competition for marine resources. In the subantarctic, marine higher predator communities are particularly species-rich and include many exceptionally mobile taxa compet- ing for often remote, patchy and unpredictable prey. Applying the above framework in this context, Croxall \& Prince (1980) concluded that although temporal and spatial differences were of some relevance, dietary specialisation was probably the primary determinant of ecological isolation. This was prior to the advent of satellite-tracking technology, which allows the precise determination of foraging areas. Therefore, the extent to which diet differences reflected spatial segregation rather than preferences for particular types of prey or feeding techniques was, at the time, uncertain. 
Subsequently, a number of comparative studies of closely-related and morphologically-similar species have related differences in diet composition during the breeding season to preferences for particular oceanographic domains, frontal zones or bathymetric regions (e.g. shelf or shelf-slope waters) (Prince et al. 1998, Waugh et al. 1999, Cherel et al. 2002, Hyrenbach et al. 2002). In theory, this could result from the competitive exclusion of subordinate by dominant species from a particular habitat, such as neritic waters close to the colony (Cherel et al. 2002), and/or reflect foraging niche-specialisation by birds differing in morphology or feeding technique (Waugh \& Weimerskirch 2003). In the broadly analogous situation of sexual segregation in highly sexually size-dimorphic seabirds, latitudinal or habitat segregation at sea was usually attributed to larger males out-competing females for access to local resources (Weimerskirch et al. 1993, González-Solís et al. 2000b). More recently, however, it was suggested that dimorphism in body mass and wing morphology plays a functional role in determining flight performance, and that the sexes might, therefore, have active preferences for more, or less, windy ocean habitats (Shaffer et al. 2001). Indeed, this is perhaps the only satisfactory explanation to why sexual segregation is apparent in 2 Thalassarche albatross species during incubation, but not during brooding or later chick-rearing when competition for nearby prey is likely to be more intense (Phillips et al. 2004).

At South Georgia (South Atlantic), the seabird community includes a guild of medium-to-large, highly mobile, opportunistic, polyphagous, aerial predators with large feeding ranges and potentially overlapping prey preferences. To a large extent, the foraging ecology of these species is well established, particularly that of wandering Diomedea exulans, and blackbrowed Thalassarche melanophrys, grey-headed albatrosses T. chrysostoma, northern Macronectes halli, and southern giant petrels $M$. giganteus, and whitechinned petrel Procellaria aequinoctialis, including determination of at-sea distribution using satellitetracking for at least part of the breeding season (Prince et al. 1998, Berrow et al. 2000, González-Solís et al. 2000a). The exception is the light-mantled sooty albatross (LMSA) Phoebetria palpebrata. Indeed, this is amongst the least known of any albatross, with detailed studies of breeding biology and demography from just 3 and 1, respectively, of the 9 breeding sites (Mougin 1970, Berruti 1979, Thomas et al. 1983, Weimerskirch et al. 1986). Movements at sea are poorly described, with only 7 complete foraging tracks from incubation or brooding published to date (Weimerskirch \& Robertson 1994, Weimerskirch 1998, Akkers 2002). Similarly, chick-provisioning rates have only fully been investigated at 1 site (South Georgia:
Thomas et al. 1983) and these were derived from daily mass increments, a technique that usually underestimates feeding frequency (Phillips \& Hamer 2000a).

The aims of the current study were to examine the provisioning and feeding strategies of LMSAs at South Georgia and, for the first time at this site, to characterise the at-sea distribution of adults using satellitetracking. Results were compared with those from the other sympatric albatrosses and petrels in the same foraging guild, particularly in terms of assessing spatiotemporal overlap in habitat utilisation. With the exception of wandering albatrosses, which rear chicks during the austral winter, and northern giant petrels, which hatch chicks a month earlier, these species overlap extensively in timing of breeding (chicks hatch in late December to mid January and fledge in late April to late May). A subsidiary purpose of the study was, therefore, to identify which other proximate mechanisms might underpin any observed spatial segregation or habitat specialisation, and serve to promote resource partitioning within this potentially highly competitive foraging environment.

\section{MATERIALS AND METHODS}

This study was carried out at Bird Island, South Georgia $\left(54^{\circ} 00^{\prime} \mathrm{S}, 38^{\circ} 03^{\prime} \mathrm{W}\right)$ from January to May 2003. Although no recent counts of LMSAs are available for South Georgia, an estimated 5000 breeding pairs were present in 1976-1977 (Thomas et al. 1983). Given the typically biennial breeding pattern in this species, but with some re-nesting in consecutive years by failed breeders, the total size of the population at South Georgia is considered to be ca. 7500 pairs, representing 30 to $35 \%$ of the world population (Thomas et al. 1983, Marchant \& Higgins 1990).

On 25 January 2003, shortly before the predicted end of brood-guard (at ca. $20 \mathrm{~d}$ after hatching: Thomas et al. 1983), 1 unsexed adult at each of 4 study nests was captured by hand and a satellite-transmitter weighing 20 or $30 \mathrm{~g}$ (PTT 100; Microwave Telemetry) attached to between 6 and 8 mantle feathers using Tesa ${ }^{\circledR}$ tape. In addition, a combined geolocator and immersion logger weighing $9 \mathrm{~g}$ (Mk. IV; British Antarctic Survey), attached to a plastic band, was fitted to 1 tarsus of each bird. This logger tests for salt-water immersion every $3 \mathrm{~s}$, integrates such events over 10 min intervals and, thereby, provides the proportion of time spent sitting on the sea as opposed to flying during this period. Total instrument mass corresponded to between 1.0 and $1.4 \%$ of the average mass $(2880 \mathrm{~g})$ of 8 breeding LMSAs weighed at the same stage of the season in 2001, a load unlikely to have any deleterious effect on the bird's performance (Phillips et 
al. 2003b). Capture, handling and release of the birds took less than $10 \mathrm{~min}$. Two individuals were later recaptured after the PTT batteries had depleted, and the $2 \mathrm{Mk}$. IV loggers and 1 PTT retrieved.

All satellite-transmitter locations in ARGOS System LC (Location Class) 3,2,1,0, A and B were filtered using an iterative forward/backward-averaging filter (McConnell et al. 1992) to remove any that required unrealistic flight speeds (filter velocity $>90 \mathrm{~km} \mathrm{~h}^{-1}$ to allow for occasional rapid commuting flights that were clearly genuine, based on visual examination). This resulted in the exclusion of $13.7 \%$ of the original 7046 locations. For each trip, we calculated the duration, maximum range (furthest distance reached from the colony) and total (cumulative) travel distance along the route (all using great-circle distances). Activity (proportion of time spent in flight) and travel speed (cumulative travel distance/total day or night length) during daylight compared with darkness were calculated from the PTT and Mk. IV logger data. Timing of civil twilight (sun $6^{\circ}$ below the horizon) was determined according to standard astronomical algorithms (Montenbruck \& Pfleger 1994).

Foraging trips were plotted individually and overlaid on maps of strong sea surface temperature (SST) gradient, sea ice extent, and wind strength and direction. SST gradient maps were used to delineate the surface expression of the subAntarctic Front and were derived from weekly Terra MODIS Level 3 mapped SST products $(4.6 \mathrm{~km}$ resolution) according to Moore et al. (1997). A strong gradient was defined as a temperature change of $\geq 1.35^{\circ} \mathrm{C}$ across a distance of ca. $45 \mathrm{~km}$. Monthly composite maps of marginal sea ice extent, corresponding to $15 \%$ ice concentration, were derived from Special Sensor Microwave Imager (SSMI) passive microwave satellite data courtesy of NOAA (National Ocean and Atmospheric Administration) and NCEP (National Centre for Environmental Prediction). Wind vectors were calculated using a numerical weather prediction model based on the European Centre for Medium Range Weather Forecasts (ECMWF) 40 yr reanalysis of historical meteorological data (ERA-40), providing a snapshot every $6 \mathrm{~h}$ at a spatial resolution of ca. $100 \mathrm{~km}$. Following Weimerskirch \& Robertson (1994), birds were considered to be flying with tail, side and head winds when the wind direction relative to the bearing of the bird was $0^{\circ}$ to $60^{\circ}, 61^{\circ}$ to $120^{\circ}$ and $121^{\circ}$ to $180^{\circ}$, respectively.

Fixed kernel home range analysis was performed on the tracking data using the Animal Movement extension (Hooge \& Eichenlaub 1997) in ArcView GIS 3.2 (ESRI). In order to reveal relatively small-scale detail, the smoothing parameter $(h)$ was set to $25 \mathrm{~km}$. Although locations were not serially independent, this is not a requirement for kernel analysis (De Solla et al.
1999). Density contours corresponding to $95,85,75$ and $50 \%$ kernels were calculated for locations in a Lambert Equal-Area Azimuthal (South Pole) projection.

A few days after brood-guard had ceased and the chick was left unattended, automated nest balances were deployed at the study nests. These record chick mass to the nearest $10 \mathrm{~g}$ every $10 \mathrm{~min}$, allowing the determination of chick growth rate, meal mass and timing of feeding from mass increments (Huin et al. 2000). Colony visits of instrumented birds were determined from the satellite locations cross-referenced to the timing of feeding and all meals were allocated to individual parents (and trip durations calculated accordingly) until PTT batteries failed. During this period, the maximum meal mass delivered by a noninstrumented bird was $1.05 \mathrm{~kg}$ and the only 2 mass increments greater than this value $(1.28$ and $1.38 \mathrm{~kg}$; both delivered later in the season) were assumed to represent closely spaced meals from both parents. Late in the season, a few days of mass data were lost because of equipment failure, in which case the feeding interval prior to the subsequent meal was not calculated.

Chick age was estimated by assuming hatching took place on 6 January (the mean in 3 previous years: Thomas et al. 1983, British Antarctic Survey unpubl. data). Hatching in LMSAs at Bird Island is highly synchronous (range 31 December to 10 January, i.e. \pm 4 to $6 \mathrm{~d}$ of the mean), and consequently, the error associated with this approach is likely to be minor, particularly as all chicks appeared to be of similar size when the automated nest balances were set up. Potential age-related changes in meal mass and chick-feeding interval were examined for chicks aged 30 to $139 \mathrm{~d}$, and adult trip duration was examined for the period that the PTTs were transmitting. These analyses exclude the first 1 to 3 trips by instrumented birds prior to deployment of the nest balances; hence, the slight variation in sample sizes. An index of chick condition was calculated as the residual from separate quadratic regressions for each chick of mass on age (Weimerskirch et al. 2000a, Phillips \& Croxall 2003), based on the mass of chicks at 05:00 h each day (i.e. the time when mass was likely to be least influenced by recent feeding history; see 'Results'). Potential relationships between chick condition at departure of the adult, subsequent trip duration and meal mass, chick condition on arrival, and the interval since the last meal (from either parent) were investigated. Survival to fledging at the 4 study nests was compared with a control sample of 23 other nests with chicks in mid to late January. Unless indicated otherwise, parametric tests were used throughout the paper and data are presented as arithmetic means $\pm \mathrm{SD}$. 


\section{RESULTS}

\section{Satellite-tracking}

Tracking data were obtained from each adult for 27 to $86 \mathrm{~d}$, corresponding to all or part of 3 to 19 foraging trips. The overall foraging area (minimum convex polygon enclosing all points) was $3.7 \times 10^{6} \mathrm{~km}^{2}$. Virtually all trips were restricted to Antarctic waters (i.e. south of the Antarctic Polar Front or APF), with none extending north of the subAntarctic Front (according to the weekly strong SST gradient maps), and only 1 passing over the Patagonian Shelf on the western Burdwood Bank (Figs. 1 \& 2). Each bird showed a considerable diversity of foraging routes (Fig. 2). Of the 38 complete trips, $10(26 \%)$ were direct to deep waters in the mid Scotia Sea, $20(53 \%)$ were to shelf $(<1000 \mathrm{~m}$ deep) and shelf-slope (1000 to $3000 \mathrm{~m}$ deep) areas along the southern Scotia Arc, where the bird either foraged in a relatively restricted area $(n=12)$ or travelled some distance east-to-west $(n=8), 2(5 \%)$ were long looping tracks over oceanic waters and $2(5 \%)$ were short trips to the local shelf, with 4 tracks (11\%) either a combination of or not otherwise falling into these categories. Only 2 trips extended into the marginal ice zone ( $>15 \%$ sea-ice cover) in the Weddell Sea (Fig. $2 \mathrm{~b}, \mathrm{c}$ ) and only 1 trip appeared to involve foraging in the region of Shag Rocks (ca. $200 \mathrm{~km}$ west of South Georgia; Fig. 1).

Tracks over oceanic water ( $>3000 \mathrm{~m}$ deep) were not associated with any discernable bathymetric or hydro-

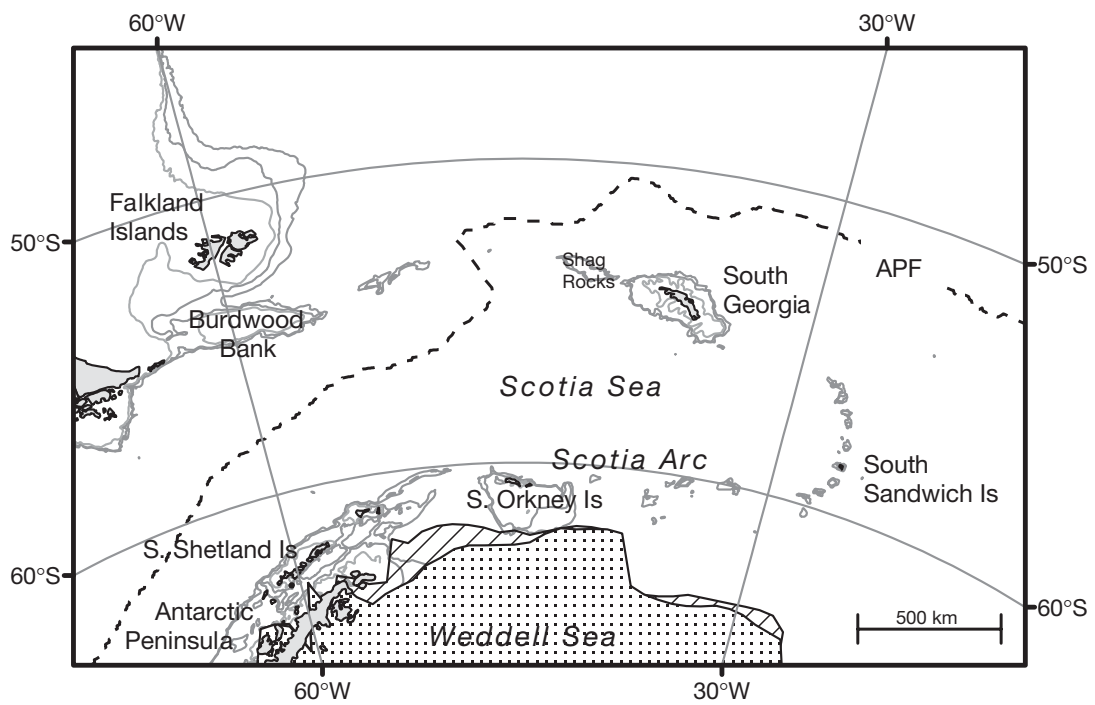

Fig. 1. Map of study area indicating the 200, 500 and $1000 \mathrm{~m}$ depth contours, the approximate long-term positions of the Antarctic Polar Front (APF) based on Moore et al. (1999) and sea ice cover in the Weddell Sea during February (dotted plus hatched areas) and March (dotted area only) 2003. For further details see text graphic features, and although a few birds crossed the $\mathrm{APF}$, none spent any appreciable time in its vicinity (Fig. 1). According to the wind vector maps, LMSA almost always travelled with side and tail winds while commuting, and very rarely against head winds. Side winds from the right were the most common en route to the Antarctic Peninsula and southern Scotia Arc region, and tail winds from the left on the return journey. Travel along the southern Scotia Arc was exclusively in a westerly direction. Wind strength and direction were important determinants of the flight route, with the few looping tracks and almost all abrupt changes in flight path in apparent response to the prevailing wind conditions (usually strong head winds encountered on the original bearing).

Kernel analyses confirmed high usage of patches of shelf and shelf-slope waters extending from west of King George Island (South Shetlands) to east of the South Orkney Islands (Fig. 3). Areas of deep oceanic water to the southwest of South Georgia were also highlighted, presumably reflecting the direct trips to the central Scotia Sea as well as the commuting routes of birds in transit from and to the Antarctic Peninsula and southern Scotia Arc. There were also 2 apparent concentrations east of the South Sandwich Islands and 1 other in the Weddell Sea, reflecting the activities of a single bird (Fig. 2b).

Considering only complete trips (Table 1), on average, LMSAs travelled an overall distance of $3795 \pm$ $2432 \mathrm{~km}$ to a mean maximum range from the colony of $921 \pm 447 \mathrm{~km}$, in trips that lasted $115 \pm 86 \mathrm{~h}$. However, foraging routes were sometimes much longer, with a total of $14(37 \%)$ covering an overall distance $>5000 \mathrm{~km}$ and 20 $(53 \%)$ to destinations $>1000 \mathrm{~km}$ from the colony. There was a highly significant correlation between trip duration and both travel distance (Spearman correlation $r_{\mathrm{s}}=0.98, \mathrm{n}=38, \mathrm{p}<0.001$ ) and maximum range (Spearman correlation $\left.r_{\mathrm{s}}=0.76, \mathrm{n}=38, \mathrm{p}<0.001\right)$. The tracked birds made extensive movements during the night, with a mean travel speed during darkness $(27.6 \mathrm{~km}$ $\mathrm{h}^{-1}$ ) equivalent to $70 \%$ of that achieved during daylight $\left(39.1 \mathrm{~km} \mathrm{~h}^{-1}\right)$. On average, $86.5 \%$ of daylight and $46.3 \%$ of darkness was spent in flight.

\section{Provisioning rates}

Two of the chicks on automated nest balances fledged successfully (aged ca. 145 and 158 d) and the other 2 killed 

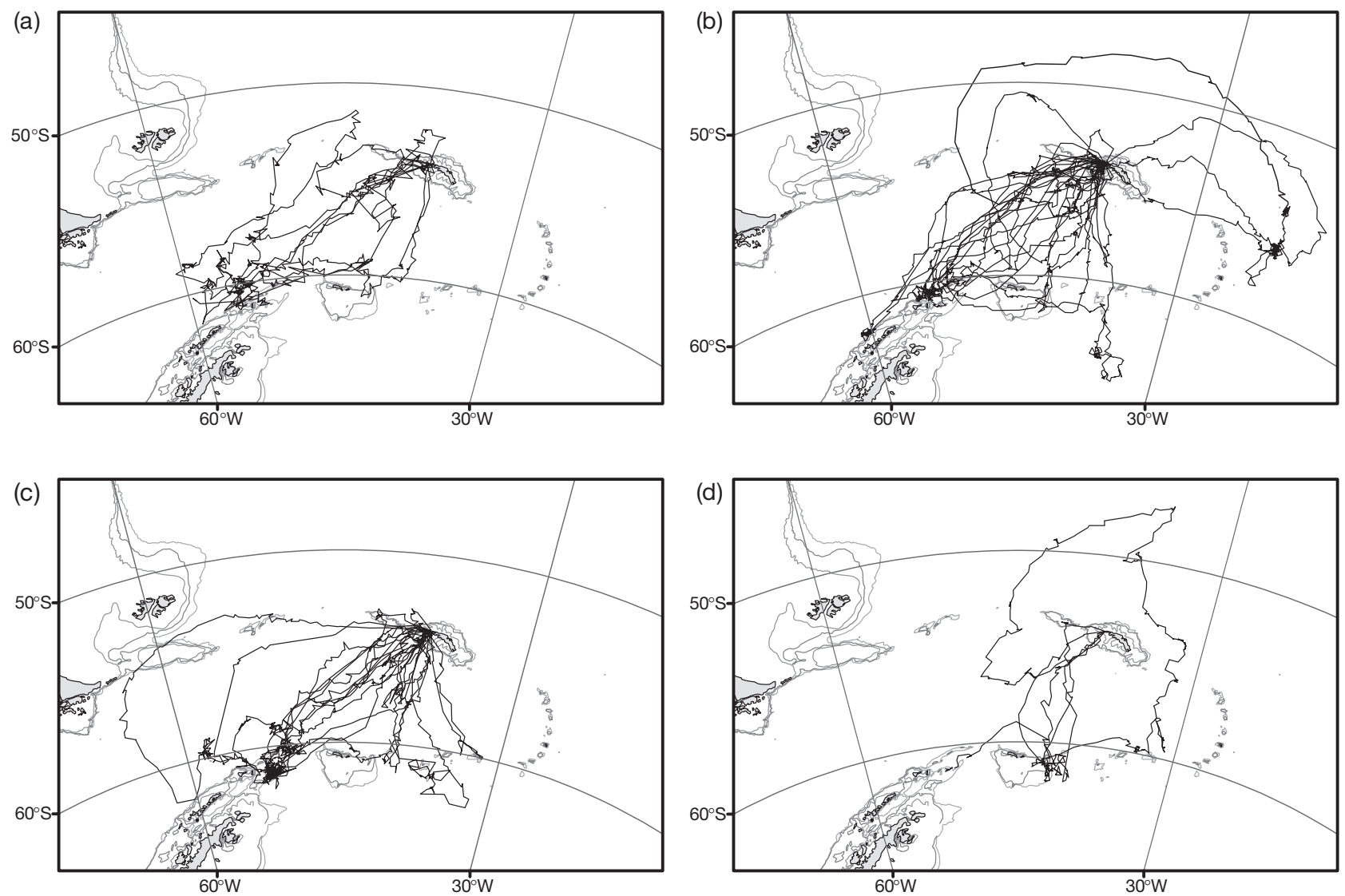

Fig. 2. Phoebetria palpebrata. Routes of the light-mantled sooty albaross (LMSAs) satellite-tracked from Bird Island, South Georgia, during chick-rearing, January to April 2003. (a) Bird 1, (b) Bird 2, (c) Bird 3 and (d) Bird 4

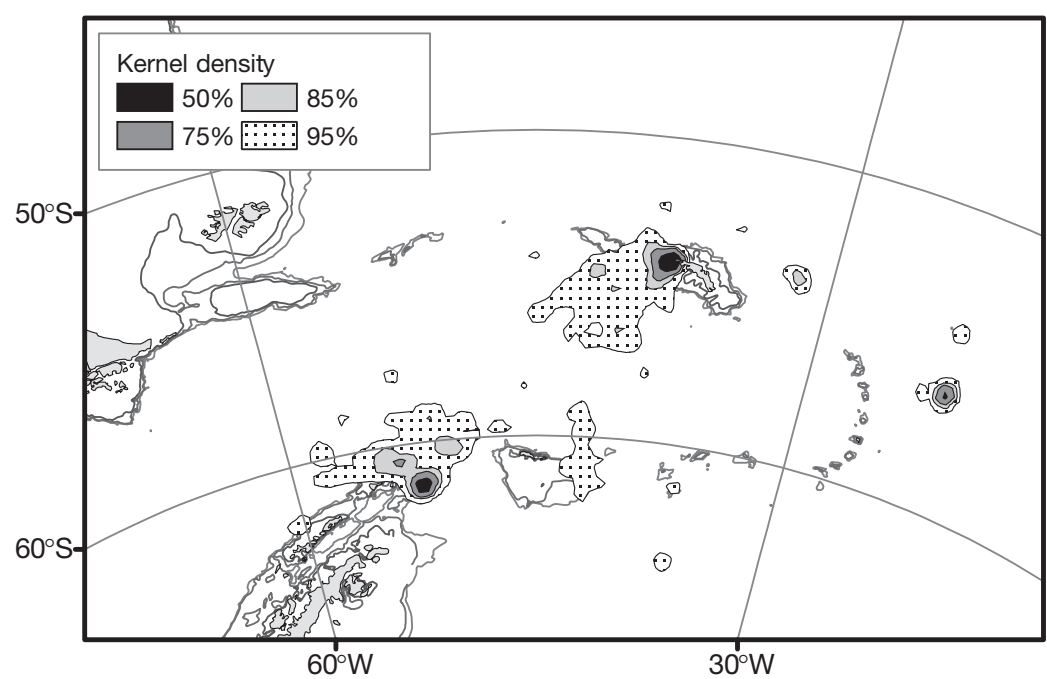

Fig. 3. Phoebetria palpebrata. Kernel density contours for LMSAs satellitetracked from Bird Island, South Georgia, during chick-rearing, January to April 2003 (aged ca. 135 and 136 d) by predators (probably brown skuas Catharacta antarctica lonnbergi). This survival rate from late brood-guard to fledging $(50 \%)$ was similar to chicks in control nests $(48 \%, \mathrm{n}=23)$.

Chicks were never fed during darkness, with the earliest meal delivered at $05: 16 \mathrm{~h}$, the latest at 20:44 $\mathrm{h}$ and the great majority (96\%) between 08:00 and 20:00 h. The frequency distribution of foraging trip durations of the 8 adults (limited to the period that the PTTs were transmitting) is shown in Fig. 4. The overall arithmetic mean foraging trip duration was $3.88 \pm 2.52 \mathrm{~d}(\mathrm{n}=69)$. Over the whole season, the overall mean chick-feeding interval was about half this value, $2.02 \pm 1.70 \mathrm{~d}(\mathrm{n}=158)$ and the overall mean meal mass was $547 \pm 177 \mathrm{~g}(\mathrm{n}=167)$. With data 
Table 1. Phoebetria palpebrata. Foraging trip characteristics of light-mantled sooty albatrosses tracked from Bird Island, South Georgia, during chick-rearing in January to April 2003. Values are means \pm SD with range in parentheses

\begin{tabular}{|c|c|c|c|c|c|c|c|c|}
\hline Bird & $\begin{array}{c}\text { Complete } \\
\text { trips }\end{array}$ & $\begin{array}{c}\text { Trip } \\
\text { duration } \\
\text { (h) }\end{array}$ & $\begin{array}{l}\text { Maximum } \\
\text { range } \\
(\mathrm{km})\end{array}$ & $\begin{array}{c}\text { Distance } \\
\text { travelled } \\
(\mathrm{km})\end{array}$ & $\begin{array}{c}\text { Speed during } \\
\text { daylight } \\
\left(\mathrm{km} \mathrm{h}^{-1}\right)^{\mathrm{a}}\end{array}$ & $\begin{array}{l}\text { Speed during } \\
\text { darkness } \\
\left(\mathrm{km} \mathrm{h}^{-1}\right)^{\mathrm{a}}\end{array}$ & $\begin{array}{c}\% \text { of } \\
\text { daylight spent } \\
\text { in flight }{ }^{\mathrm{a}}\end{array}$ & $\begin{array}{c}\% \text { of } \\
\text { darkness spent } \\
\text { in flight }{ }^{\mathrm{a}}\end{array}$ \\
\hline 1 & 5 & $\begin{array}{c}130 \pm 84 \\
(11-241)\end{array}$ & $\begin{array}{r}1091 \pm 594 \\
\quad(66-1502)\end{array}$ & $\begin{array}{r}5021 \pm 3025 \\
(320-8547)\end{array}$ & $\begin{array}{l}29.1 \pm 5.0 \\
(25.6-32.7)\end{array}$ & $\begin{array}{l}21.0 \pm 7.8 \\
(15.5-26.5)\end{array}$ & $\begin{array}{l}91.4 \pm 1.0 \\
(90.2-92.3)\end{array}$ & $\begin{array}{l}50.0 \pm 21.1 \\
(30.0-76.9)\end{array}$ \\
\hline 2 & 18 & $\begin{array}{c}107 \pm 83 \\
(20-289)\end{array}$ & $\begin{array}{c}881 \pm 465 \\
(94-1613)\end{array}$ & $\begin{array}{r}3392 \pm 2208 \\
(373-7456)\end{array}$ & $\begin{array}{l}39.4 \pm 5.1 \\
(32.5-46.3)\end{array}$ & $\begin{array}{l}30.1 \pm 10.2 \\
(13.3-49.5)\end{array}$ & - & - \\
\hline 3 & 13 & $\begin{array}{c}101 \pm 65 \\
(26-211)\end{array}$ & $\begin{array}{l}915 \pm 420 \\
(326-1708)\end{array}$ & $\begin{array}{r}3582 \pm 2290 \\
(977-7110)\end{array}$ & $\begin{array}{l}39.7 \pm 8.6 \\
(26.2-57.9)\end{array}$ & $\begin{array}{r}24.7 \pm 10.5 \\
(7.1-51.2)\end{array}$ & - & - \\
\hline 4 & 2 & $\begin{array}{l}236 \\
(89-383)\end{array}$ & $\begin{array}{l}893 \\
(868-918)\end{array}$ & $\begin{array}{l}5744 \\
(2761-8726)\end{array}$ & $\begin{array}{l}40.5 \pm 2.5 \\
(37.9-44.1)\end{array}$ & $\begin{array}{l}34.1 \pm 11.8 \\
(21.0-49.5)\end{array}$ & $\begin{array}{l}78.3 \pm 9.4 \\
(71.2-89.0)\end{array}$ & $\begin{array}{l}40.1 \pm 13.0 \\
(28.2-54.0)\end{array}$ \\
\hline All & 38 & $\begin{array}{c}115 \pm 86 \\
(11-383)\end{array}$ & $\begin{array}{l}921 \pm 447 \\
(66-1708)\end{array}$ & $\begin{array}{r}3795 \pm 2432 \\
(320-8726)\end{array}$ & $\begin{array}{l}39.1 \pm 7.0 \\
(25.6-57.9)\end{array}$ & $\begin{array}{r}27.6 \pm 10.7 \\
(7.1-51.2)\end{array}$ & $\begin{array}{l}86.5 \pm 8.5 \\
(71.2-92.3)\end{array}$ & $\begin{array}{c}46.3 \pm 18 \\
(28.2-76.9)\end{array}$ \\
\hline
\end{tabular}

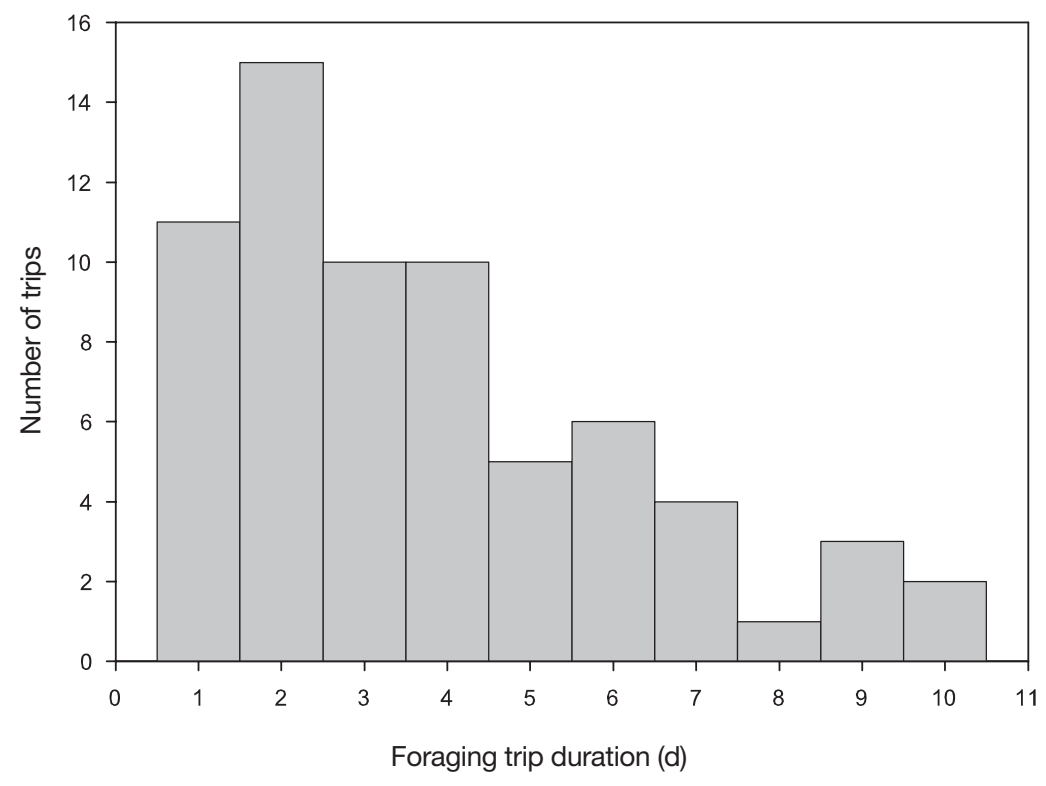

Fig. 4. Phoebetria palpebrata. Frequency distribution of foraging trip durations by LMSAs on Bird Island, South Georgia during chick-rearing

ther meal mass or trip duration (1-way ANOVAs, $F_{7,61}=1.2, \mathrm{p}=0.32$ and $F_{7,61}=0.3, \mathrm{p}=94$, respectively), with the mean meal mass for each adult ranging from 456 to $680 \mathrm{~g}$ and mean trip duration from 3.4 to $5.1 \mathrm{~d}$; nor was there a significant effect of PTT attachment, with no significant differences between instrumented birds and their partner in mean trip duration (Paired $t$-test, $t_{3}=0.5, \mathrm{p}=0.65$ ) or mean meal mass (paired $t$-test, $t_{3}=$ 1.9, $\mathrm{p}=0.15)$.

There was no correlation between chick condition on one visit and the subsequent foraging trip duration by the same adult (Pearson correlation $\left.r_{65}=0.14, \mathrm{p}=0.26\right)$, nor the mass of the meal delivered at the end of that trip $\left(r_{64}=0.18, \mathrm{p}=0.15\right)$. However, there was a significant positive correlation between meal mass and both the duration of the foraging trip $\left(r_{64}=\right.$ 0.36, $\mathrm{p}<0.005$ ) and the interval since the previous meal from either parent

grouped into $10 \mathrm{~d}$ periods, there was no significant effect of chick age on feeding interval (1-way ANOVA, $F_{9,148}=1.0, \mathrm{p}=0.45$ ) or foraging trip duration (1-way ANOVA, $\left.F_{5,61}=0.7, \mathrm{p}=0.65\right)$, but there was on meal mass (1-way ANOVA, $F_{9,157}=2.0, \mathrm{p}<0.05$ ). However, meal mass showed no consistent pattern of increase or decrease over time, nor any significant pairwise differences between $10 \mathrm{~d}$ periods as indicated by Scheffé ranges tests.

Considering potential individual effects, there were no consistent differences among the 8 adults in ei- $\left(r_{64}=0.35, \mathrm{p}<0.005\right)$, but not the mass of the previous meal $\left(r_{63}=0.02, \mathrm{p}=0.89\right)$. Chicks that had been left unfed for longer were in significantly poorer body condition $\left(r_{65}=-0.51, \mathrm{p}<0.001\right)$, but the correlation between meal mass and the condition of the chick on arrival of the adult was not significant $\left(r_{64}=\right.$ $-0.21, \mathrm{p}=0.09$ ). In a stepwise multiple regression, with all appropriate variables available for entry, meal mass showed the strongest relationship with foraging trip duration $\left(F_{1,64}=9.8, \mathrm{p}<0.005\right)$, with no other variables entering the model. 


\section{DISCUSSION}

\section{Foraging site preferences}

This, the first detailed study of the foraging strategies and at-sea distribution of LMSAs breeding at South Georgia, revealed a diversity of foraging routes and feeding sites used by adults during chick-rearing (Fig. 2). The most important habitats were shelf and shelf-slope waters of the southern Scotia Arc, and deep water in the central Scotia Sea (in total accounting for $79 \%$ of all trips). LMSA also visited the marginal ice zone in the Weddell Sea and were occasionally tracked on long, looping routes to the north and, in one case, over the southeast portion of the Patagonian Shelf, but such trips were rare. This distribution conforms fairly well to the pattern of at-sea observations (Thomas 1982). The latter suggested slightly more use of waters to the west and north of South Georgia, but as the origin, age and reproductive status of birds seen at sea is unknown, such records could easily be attributable to juveniles, failed breeders or non-breeding birds.

The locations and feeding habitats typical of the tracked birds were in accordance with the single diet study carried out in the late 1970s (Thomas 1982). At that time, the major prey by mass were squid (46\%), crustacea (40\%; predominantly Antarctic krill Euphausia superba) and fish (11\%; mainly lanternfishes Myctophidae and some Antarctic cods Nototheniidae). The principal squid by frequency of occurrence were Galiteuthis glacialis $(60 \%)$ and Psychroteuthis glacialis (20\%) (Prince \& Morgan 1987). Both are typically Antarctic species and regularly recorded in scientific net hauls at the Antarctic Peninsula and Scotia Arc (Xavier et al. 1999), i.e. co-extensive with the core foraging areas of LMSA in this study. Diet samples from grey-headed albatrosses returning from the Antarctic Peninsula region, and from white-chinned petrels returning from near the South Orkneys, also include krill (Berrow et al. 2000, Xavier et al. 2003). The LMSA probably also target krill when they visit these regions.

The low incidence of the squid Martialia hyadesi and Kondakovia longimana, and the absence of Illex argentinus in the diet of LMSA (Thomas 1982, Prince \& Morgan 1987) is equally informative. M. hyadesi is common close to the APF, and consumed in large numbers by grey-headed and black-browed albatrosses that visit this area (Rodhouse et al. 1996). K. longimana dominates the diet of wandering albatrosses, which feed predominantly (although not exclusively) in warm, pelagic waters to the north and northwest of South Georgia (Prince \& Morgan 1987, Prince et al. 1998), and I. argentinus is taken by white-chinned petrels at the Falklands Shelf and Patagonian Shelf (Berrow et al. 2000). The rarity or absence of these 3 squid species in LMSA diet agrees with the results of our tracking study: the almost exclusively Antarctic direction of the tracks, the rarity of trips to the Patagonian Shelf and the absence, despite its close proximity, of foraging at the APF (Fig. 2).

\section{Comparison with other studies}

The few previous published satellite-tracks from LMSA at Macquarie, Crozet and Marion Islands were from the incubation or brooding periods (Weimerskirch \& Robertson 1994, Weimerskirch 1998, Akkers 2002). These studies show several parallels with the South Georgia data. At all sites, LMSA tended to commute fairly rapidly to specific areas in Antarctic/subAntarctic waters, where they spent most of their foraging time, and only rarely undertook the long, looping tracks typical of several other albatross species (Weimerskirch 1998). Foraging ranges were usually very large, with LMSA appearing to maximise travel speeds (also see Weimerskirch \& Robertson 1994) by exploiting the prevailing winds. The airflow is predominantly easterly in the Scotia Sea region and birds from South Georgia exploit this by following a stereotypical flight path involving a clockwise route to and from the southern Scotia Arc. In this way, they avoid head winds when heading south and take advantage of tail winds from the left to facilitate rapid return from the Antarctic Peninsula. LMSA from Macquarie Island similarly avoid head winds wherever possible (Weimerskirch \& Robertson 1994). Finally, it is worth noting that LMSA never make extensive use of well-defined frontal systems.

One striking departure from previous studies was the extensive use of Antarctic shelf and shelf-slope waters by LMSA from South Georgia. This is also reflected in dietary variation among birds from different colonies, with krill much more important at South Georgia than elsewhere (Ridoux 1994, Cooper \& Klages 1995, Green et al. 1998). In terms of squid species, there is only moderate overlap, with Kondakovia longimana considerably more important at Heard, Macquarie, Marion and Crozet Islands, and several taxa recorded elsewhere absent from the diet at South Georgia (Berruti \& Harcus 1978, Ridoux 1994, Cooper \& Klages 1995, Green et al. 1998). By comparison, the dominant taxon by mass at South Georgia is the squid Psychroteuthis glacialis, which presumably reflects the closer proximity of Antarctic ice edge habitat to LMSA at this breeding location than to those from the other, more northerly colonies. 


\section{Activity pattern}

On average, the LMSA spent $86 \%$ of daylight and $46 \%$ of darkness in flight, with mean travel speeds of 39.1 and $27.6 \mathrm{~km} \mathrm{~h}^{-1}$, respectively. Relative speed was, therefore, not in proportion to the level of flight activity, perhaps because during daylight, foraging birds were more likely to engage in area-restricted searching for prey and, hence, took more sinuous flight paths between satellite fixes. Compared with other albatrosses during the post-brood period, LMSA spend a proportion of daylight in flight that is similar to greyheaded albatrosses, and slightly more than yellownosed Thalassarche chlororhynchos and black-browed albatrosses, but much more of the night in flight than in any other species (Weimerskirch \& Guionnet 2002, Catry et al. 2004). This may allow them to reach distant foraging grounds more rapidly and to spend a greater proportion of their time actively searching for prey. Further inter-specific comparisons of activity pattern are confounded by differences in methodology, including stage of the season, the use of sunset/sunrise or civil/nautical twilight to discriminate between day and night, the approach used to filter the bird locations and calculate travel speed and distance etc., as well as the potential influence of moon phase.

Given this high degree of nocturnal activity, it is noteworthy that the majority of squid by number (although not mass) consumed by LMSA at Marion Island is bioluminescent (Berruti \& Harcus 1978), hence, the suggestion that LMSA may feed predominantly at night, when many squid and Antarctic krill (their other main prey at South Georgia) perform extensive diel vertical migrations that bring them closer to the surface (Thomas 1982). However, other authors have argued that the importance of bioluminescence in facilitating prey capture has probably been over-stated, and that it is more pertinent that the majority of squid in the diet is large and positively buoyant, and hence, potentially scavenged near the surface when dead or moribund after spawning (Croxall \& Prince 1994, Cooper \& Klages 1995). Although wandering albatrosses feed relatively little at night (Weimerskirch \& Wilson 1992), grey-headed albatrosses consumed $26 \%$ of their prey by mass during darkness, mostly using a sit-and-wait tactic whilst on the sea surface (Catry et al. 2004). As the nights were shorter, this equated to an intake rate in grey-headed albatrosses during darkness of $61 \%$ of that achieved in daylight (Catry et al. 2004). It would clearly be instructive to have independent records of the timing of ingestion events in LMSA and to determine whether they behave similarly. At present, without higher resolution data, it is difficult to determine whether LMSA high flight activity during the night mainly reflects commuting between prey patches (within which birds then switch to area-restricted searching or to sittingand-waiting) or is essentially a linear searching method to locate bioluminescent prey whilst on the wing.

\section{Provisioning strategies}

The meal mass of LMSA at South Georgia in 2003 $(547 \pm 177 \mathrm{~g})$ was very similar to the mass of food regurgitated by adults about to feed chicks in 1977 (557 \pm 175 g: Thomas et al. 1983). Mean adult trip duration was $3.9 \mathrm{~d}$ and chick-feeding interval was $2.02 \mathrm{~d}$ in 2003, with the latter, as expected, slightly shorter than that calculated from daily chick weights in previous studies both at South Georgia (2.2 d: Thomas et al. 1983) and Marion Island (2.6 d: Berruti 1979). Therefore, although our sample size (in terms of the number of nests) was relatively small, the results match previous work very well. Compared with the other medium to large albatrosses and petrels breeding at South Georgia, LMSA chicks are fed less frequently, although with relatively larger meals (Table 2). They also gain weight less rapidly than do other species of albatross and, given their smaller mass, take relatively longer to fledge (Thomas et al. 1983). This disparity is not related to intrinsic physiological constraints, as there are no fundamental differences in mass-specific metabolic rates of LMSA, grey-headed or blackbrowed albatross chicks during the linear phase of development (Phillips et al. 2003a). Therefore, the inter-specific variation in growth up until peak mass should be attributed almost exclusively to variation in the rate of energy delivery by parents.

The average mass of a chick feed corresponds to $19 \%$ of mean adult mass $(2880 \mathrm{~g})$, a greater percentage than in any other albatross or large petrel (Phillips \& Hamer 2000b; Table 2). Adult LMSA, therefore, partly compensate for their low feeding frequency by providing relatively large meals. There is no evidence that they increase energy delivery rate by providing meals of unusually high caloric value compared with other albatrosses. The ratio of solid:liquid in adult regurgitates is similar in LMSA, black-browed and greyheaded albatrosses (Thomas 1982). In addition, the ratio of lipid:water in the liquid portion is determined primarily by food type, with meals of krill having the highest lipid content (Clarke \& Prince 1980), and the diets of LMSA and black-browed albatrosses at South Georgia include similar proportions of krill (Thomas 1982, Croxall et al. 1997).

There was no correlation in our study between chick body condition and the subsequent foraging trip duration or meal mass delivered by the adult on its return; 
Table 2. Mean foraging trip characteristics and provisioning rates of medium to large, summer-breeding albatrosses and petrels at Bird Island, South Georgia

\begin{tabular}{|c|c|c|c|c|c|c|c|c|c|}
\hline Species & & $\begin{array}{l}\text { Adult } \\
\text { mass }^{\mathrm{a}} \\
(\mathrm{g})\end{array}$ & $\begin{array}{l}\text { Chick- } \\
\text { feeding } \\
\text { interval }^{\mathrm{b}} \\
\text { (d) }\end{array}$ & $\begin{array}{l}\text { Chick } \\
\text { meal } \\
\text { mass } \\
(\mathrm{g})\end{array}$ & $\begin{array}{c}\text { Meal } \\
\text { mass } \\
\text { (\% adult } \\
\text { mass })\end{array}$ & $\begin{array}{l}\text { Daily } \\
\text { food } \\
\text { intake } \\
\left(\mathrm{g} \mathrm{d}^{-1}\right)\end{array}$ & $\begin{array}{l}\text { Distance } \\
\text { travelled }^{\mathrm{d}} \\
\quad(\mathrm{km})\end{array}$ & $\begin{array}{l}\text { Maxi- } \\
\text { mum } \\
\text { range }^{\mathrm{d}} \\
(\mathrm{km})\end{array}$ & Source \\
\hline \multicolumn{10}{|l|}{ Light-mantled sooty albatross } \\
\hline Phoebetria palpebrata & & 2880 & 2.02 & 547 & 19.0 & 271 & 3795 & 921 & This study \\
\hline \multicolumn{10}{|l|}{ Black-browed albatross } \\
\hline Thalassarche melanophry & & 3460 & 1.22 & 569 & 16.4 & 466 & 1726 & 421 & Huin et al. (2000) \\
\hline \multicolumn{10}{|l|}{ Grey-headed albatross } \\
\hline $\begin{array}{l}\text { Thalassarche chrysostoma } \\
\text { Northern giant petrel }\end{array}$ & \multicolumn{8}{|c|}{ Northern giant petrel } & Huin et al. (2000) \\
\hline Macronectes halli & \multicolumn{4}{|c|}{3390 (females) } & $\begin{array}{l}5.6 \\
7.9\end{array}$ & 560 & - & - & Hunter (1983) \\
\hline \multicolumn{10}{|l|}{ Southern giant petrel } \\
\hline Macronectes giganteus & \multicolumn{2}{|c|}{3340 (females) } & 0.52 & 345 & $\begin{array}{c}7.3 \\
10.3\end{array}$ & 663 & - & - & Hunter (1983) \\
\hline $\begin{array}{l}\text { White-chinned petrel } \\
\text { Procellaria aequinoctialis }\end{array}$ & & 1300 & 1.47 & 198 & 15.2 & 135 & 2808 & 751 & $\begin{array}{l}\text { Croxall et al. (1995), } \\
\text { Berrow et al. (2000) }\end{array}$ \\
\hline $\begin{array}{l}{ }^{\mathrm{a}} \text { Cited reference or unpubl. } \\
\mathrm{b} \text { Excludes chicks }<20 \mathrm{~d} \text { old } \\
{ }^{\mathrm{c}} \text { Calculated from feeding fre } \\
\text { d Unpubl. analyses of } 19 \text { to } \\
\text { post-guard chick-rearing }\end{array}$ & $\begin{array}{l}\text { data } \\
\text { eque } \\
238\end{array}$ & $\begin{array}{l}\text { ency } \times \text { meal } \\
\text { foraging tri }\end{array}$ & $\begin{array}{l}1 \text { mass } \\
\text { rips (dep }\end{array}$ & ding & he spec & by b & ds fitted & h sate & -transmitters durin \\
\hline
\end{tabular}

nor did meal mass correlate significantly with chick condition on arrival of the adult. LMSA, therefore, seem to have little leeway to modify provisioning patterns according to the nutritional demands of the chick. The inability to increase the feeding rate of poorly fed chicks, in particular, implies either the absence of alternative feeding sites closer to the colony with sufficiently high and predictable prey concentrations, or if such areas do exist, that adult LMSA are unable to exploit them effectively. In Procellariiformes in general, species which feed the chick relatively frequently (every 1 to $3 \mathrm{~d}$ ) often show some capacity to respond to chick condition, whereas those that return less often generally do not (Bolton 1995, Granadeiro et al. 1998, Weimerskirch et al. 2000a, Phillips \& Croxall 2003). With an average trip duration of 3.9 d, LMSA therefore fit with this general pattern.

\section{Spatial segregation}

The overall foraging range utilised by LMSA during chick-rearing is more or less co-extensive with most other albatrosses and large petrels breeding at South Georgia (Prince et al. 1998, Berrow et al. 2000). The exceptions are wandering albatrosses, which tend to be distributed further to the north and west in February to April, corresponding to their late incubation and brooding period (Xavier et al. 2003, British Antarctic
Survey unpubl. data), and probably giant petrels, which given their high feeding frequency (see Table 2) and reliance, to a large extent, on seal and penguin carrion during chick-rearing (Hunter 1983), presumably feed closer to the colony. The latter needs to be confirmed by satellite-tracking of giant petrels during chick-rearing, as their foraging areas during incubation do overlap with those of LMSA (González-Solís et al. 2000a).

The greatest areas of overlap are within shelf and shelf-slope waters on the southern Scotia Arc, of which the western portion is exploited by sympatric blackbrowed and grey-headed albatrosses, and the eastern by white-chinned petrels (Prince et al. 1998, Berrow et al. 2000). Unlike LMSA, black-browed albatrosses and white-chinned petrels also commonly exploit the surrounding South Georgia shelf and shelf-slope, and both black-browed and grey-headed albatrosses routinely forage at the APF. Hence, the average travel distance and range of LMSA during chick-rearing is considerably greater than in these other species (Table 2).

All 4 species show considerable overlap in diets, which consist of squid, fish and krill in various proportions (Thomas 1982, Croxall et al. 1997), and they can be regarded as belonging to the same broad guild of highly mobile, generalist predators. It is, therefore, surprising that LMSA do not utilise these alternative local sites that are obviously key foraging grounds for the other species, as well as for wandering albatrosses, 
particularly during brooding (Xavier et al. 2003). One possible explanation relates to the considerable interspecific disparities in body mass (see Table 2). Cherel at al. (2002) postulated that size inequalities probably accounted for the different proportions of neritic versus oceanic prey in the diet of 3 sympatric albatrosses from Kerguelen. Larger albatrosses tend to out-compete smaller species when foraging (Weimerskirch et al. 1986), and there is empirical evidence that blackbrowed albatrosses initiate and then dominate multispecies feeding flocks close to South Georgia (Harrison et al. 1991). Moreover, compared with other species, LMSA rarely attend fishing vessels (Weimerskirch et al. 2000b), suggesting that they do not compete effectively in dense predator aggregations. It is, therefore, likely that LMSA would lose in competitive interactions with other albatrosses in waters close to South Georgia and are, thus, forced to use more distant foraging grounds.

Of course, size-mediated dominance cannot explain why white-chinned petrels (which weigh only $1300 \mathrm{~g}$ ), but not LMSA, are able to exploit local neritic waters. However, other mechanisms could regulate the degree of inter-specific competition. Although both feed mainly by surface-seizing (Harper 1987), and there is little disparity in diving capability (both regularly dive to $5 \mathrm{~m}$ and are able to achieve $12 \mathrm{~m}_{i}$ Huin 1994, Prince et al. 1994), white-chinned petrels probably feed even more at night than LMSA, and being so much smaller are probably much more manoeuvrable (Harper 1987), each of which is likely to broaden their foraging niche and reduce competition with Thalassarche albatrosses.

In conclusion, the co-existence of LMSA with other highly mobile, generalist seabird predators at South Georgia is facilitated to a large extent by spatial segregation in foraging areas. This segregation is, however, far from absolute. Although LMSA is the only species that routinely concentrates its foraging effort during chick-rearing in distant Antarctic shelf and shelf-slope waters, sympatric Thalassarche albatrosses and whitechinned petrels also exploit these sites. At least for grey-headed albatrosses, this is in response to poor foraging conditions encountered close to South Georgia and is associated with poor breeding success (Xavier et al. 2003, Catry et al. 2004). LMSA, by contrast, can exploit such remote sites and still rear chicks successfully, perhaps because they are the most aerial of the South Georgia albatrosses, with particularly low wing loading and high aspect ratio (Warham 1977) and are, therefore, able to cover greater distances more efficiently. Whether or not such adaptations mean that LMSA from South Georgia show similar habitat preferences during the winter, when adults are no longer constrained to be central-place foragers, has yet to be revealed; nor is it known whether they allow LMSA to fledge chicks in years of low krill abundance in the north Scotia Sea, when the other krill-dependent predators tend to fail completely.

Acknowledgements. We are very grateful to B. Phalan, N. Warren and J. Tanton for help with fieldwork at Bird Island, D. Briggs for logistical support and M. Francis for technical advice on the automatic nest balances. J. Cooper, K. D. Hyrenbach and 2 anonymous referees provided numerous helpful comments on an earlier draft of the manuscript. A. Fleming and G. Marshall kindly helped provide the remotely sensed datasets. SST data were obtained from http://daac.gsfc.nasa.gov/ MODIS/. The Animal Movement extension to ArcView GIS was downloaded from http://www.absc.usgs.gov/glba/gistools/ and the code that implements the algorithms of Montenbruck \& Pfleger (1994) was obtained from http://www.xylem.f2s.com/ kepler/moonrise.html.

\section{LITERATURE CITED}

Akkers T (2002) Research in the Southern Oceans. In: Research highlights 2001-2002, Vol 11. Department of Environmental Affairs and Tourism, Pretoria, p 78-82

Ashmole N, Ashmole MJ (1967) Comparative feeding ecology of seabirds of a tropical oceanic island. Peabody Mus Nat Hist Bull 24:1-131

Bédard J (1976) Coexistence, coevolution and convergent evolution in seabird communities: a comment. Ecology 57 : 177-184

Berrow SD, Wood AG, Prince PA (2000) Foraging location and range of white-chinned petrels Procellaria aequinoctialis breeding in the South Atlantic. J Avian Biol 31:303-311

Berruti A (1979) The breeding biologies of the sooty albatrosses Phoebetria fusca and P. palpebrata. Emu 79: 161-175

Berruti A, Harcus T (1978) Cephalopod prey of the sooty albatrosses Phoebetria fusca and P. palpebrata at Marion Island. S Afr J Antarct Res 8:99-103

Bolton M (1995) Food delivery to nestling storm petrels: limitation or regulation? Funct Ecol 9:161-170

Catry P, Phillips RA, Phalan B, Silk JRD, Croxall JP (2004) Foraging strategies of grey-headed albatrosses Thalassarche chrysostoma: integration of movements, activity and feeding events. Mar Ecol Prog Ser 280:261-273

Cherel Y, Weimerskirch H, Trouvé C (2002) Dietary evidence for spatial foraging segregation in sympatric albatrosses (Diomedea spp.) rearing chicks at Iles Nuageuses, Kerguelen. Mar Biol 141:1117-1129

Clarke A, Prince PA (1980) Chemical composition and calorific value of food fed to mollymauk chicks Diomedea melanophris and D. chrysostoma at Bird Island, South Georgia. Ibis 122:488-494

Cody ML (1973) Coexistence, coevolution and convergent evolution in seabird communities. Ecology 54:31-44

Cooper J, Klages NTW (1995) The diets and dietary segregation of sooty albatrosses (Phoebetria spp.) at subAntarctic Marion Island. Antarct Sci 7:15-23

Croxall JP, Prince PA (1980) Food, feeding ecology and ecological segregation of seabirds at South Georgia. Biol J Linn Soc 14:103-131

Croxall JP, Prince PA (1994) Dead or alive, night or day - how do albatrosses catch squid? Antarct Sci 6:155-162

Croxall JP, Hall AJ, Hill HJ, North AW, Rodhouse PG (1995) The food and feeding ecology of the white-chinned petrel Procellaria aequinoctialis at South Georgia. J Zool 237: 133-150 
Croxall JP, Prince PA, Reid K (1997) Dietary segregation of krill-eating South Georgia seabirds. J Zool 242:531-556

De Solla SR, Bonduriansky R, Brooks RJ (1999) Eliminating autocorrelation reduces biological relevance of home range estimates. J Anim Ecol 68:221-234

González-Solís J, Croxall JP, Wood AG (2000a) Foraging partitioning between giant petrels Macronectes spp. and its relationship with breeding population changes at Bird Island, South Georgia. Mar Ecol Prog Ser 204:279-288

González-Solís J, Croxall JP, Wood AG (2000b) Sexual size dimorphism and sexual segregation in foraging strategies of northern giant petrels, Macronectes halli, during incubation. Oikos 90:390-398

Granadeiro JP, Nunes M, Silva MC, Furness RW (1998) Flexible foraging strategy of Cory's shearwater Calonectris diomedea during the chick rearing period. Anim Behav 56:1169-1176

Green K, Kerry KR, Disney T, Clarke MR (1998) Dietary studies of light-mantled sooty albatrosses Phoebetria palpebrata from Macquarie and Heard Islands. Mar Ornithol 26: $19-26$

Harper PC (1987) Feeding behaviour and other notes on 20 species of Procellariiformes at sea. Notornis 34:169-192

Harrison NM, Whitehouse MJ, Heinemann MJ, Prince PA, Hunt GL, Veit RR (1991) Observations of multispecies seabird flocks around South Georgia. Auk 108:801-810

Hooge PN, Eichenlaub B (1997) Animal movement extension to ArcView, version 1.1. US Geological Survey, Anchorage, AK

Huin N (1994) Diving depths of white-chinned petrels. Condor 96:1111-1113

Huin N, Prince PA, Briggs DR (2000) Chick provisioning rates and growth in black-browed albatross Diomedea melanophris and grey-headed albatross D. chrysostoma at Bird Island, South Georgia. Ibis 142:550-565

Hunter S (1983) The food and feeding ecology of the giant petrels Macronectes halli and M. giganteus at South Georgia. J Zool 200:521-538

Hyrenbach KD, Fernández P, Anderson DJ (2002) Oceanographic habitats of two sympatric North Pacific albatrosses during the breeding season. Mar Ecol Prog Ser 233: 283-301

Marchant S, Higgins PJ (1990) Handbook of Australian, New Zealand and Antarctic birds, Vol 1. Oxford University Press, Melbourne

McConnell BJ, Chambers C, Fedak MA (1992) Foraging ecology of southern elephant seals in relation to bathymetry and productivity of the Southern Ocean. Antarct Sci 4: 393-398

Montenbruck O, Pfleger T (1994) Astronomy on the personal computer, 3rd edn. Springer-Verlag, Berlin

Moore JK, Abbott MR, Richman JG (1997) Variability in the location of the Antarctic Polar Front $\left(90^{\circ}-20^{\circ} \mathrm{W}\right)$ from satellite sea surface temperature data. J Geophys Res Oceans 102:27825-27833

Moore JK, Abbott MR, Richman JG (1999) Location and dynamics of the Antarctic Polar Front from satellite sea surface temperature data. J Geophys Res Oceans 104: 3059-3073

Mougin JL (1970) Les albatros fuligineux Phoebetria palpebrata and P. fusca de l'ile de la Possession (Archipel Crozet). Oiseau 40:37-61

Pearson TH (1968) The feeding ecology of sea-bird species breeding on the Farne Islands, Northumberland. J Anim Ecol 37:521-552

Phillips RA, Croxall JP (2003) Control of provisioning in greyheaded albatrosses (Thalassarche chrysostoma): Do adults respond to chick condition? Can J Zool 81:111-116

Phillips RA, Hamer KC (2000a) Periodic weighing and the assessment of meal mass and feeding frequency in seabirds. J Avian Biol 31:75-80

Phillips RA, Hamer KC (2000b) Provisioning and growth strategies of northern fulmars, Fulmarus glacialis. Ibis 142: 435-445

Phillips RA, Green JA, Phalan B, Croxall JP, Butler PJ (2003a) Chick metabolic rate and growth in three species of albatross: a comparative study. Comp Biochem Physiol A 135: 185-193

Phillips RA, Xavier JC, Croxall JP (2003b) Effects of satellite transmitters on albatrosses and petrels. Auk 120: $1082-1090$

Phillips RA, Silk JRD, Phalan B, Catry P, Croxall JP (2004) Seasonal sexual segregation in two Thalassarche albatrosses: competitive exclusion, reproductive role specialization or foraging niche divergence? Proc R Soc Lond B 271:1283-1291

Prince PA, Morgan RA (1987) Diet and feeding ecology of Procellariiformes. In: Croxall JP (ed) Seabirds: feeding ecology and role in marine ecosystems. Cambridge University Press, Cambridge, p 135-171

Prince PA, Huin N, Weimerskirch H (1994) Diving depths of albatrosses. Antarct Sci 6:353-354

Prince PA, Croxall JP, Trathan PN, Wood AG (1998) The pelagic distribution of South Georgia albatrosses and their relationships with fisheries. In: Robertson G, Gales R (eds) Albatross biology and conservation. Surrey Beatty \& Sons, Chipping Norton, p 137-167

Ridoux V (1994) The diets and dietary segregation of seabirds at the subantarctic Crozet Islands. Mar Ornithol 22:1-192

Rodhouse PG, Prince PA, Trathan PN, Hatfield EMC, Watkins JL, Bone DG, Murphy EJ, White MG (1996) Cephalopods and mesoscale oceanography at the Antarctic Polar Front: satellite tracked predators locate pelagic trophic interactions. Mar Ecol Prog Ser 136:37-50

Shaffer SA, Weimerskirch H, Costa DP (2001) Functional significance of sexual dimorphism in wandering albatrosses, Diomedea exulans. Funct Ecol 15:203-210

Thomas G (1982) The food and feeding ecology of the lightmantled sooty albatross at South Georgia. Emu 82:92-100

Thomas G, Croxall JP, Prince PA (1983) Breeding biology of the light-mantled sooty albatross (Phoebetria palpebrata) at South Georgia. J Zool 199:123-135

Warham J (1977) Wing loadings, wing shapes, and flight capabilities of Procellariiformes. NZ J Zool 4:73-83

Waugh S, Weimerskirch H (2003) Environmental heterogeneity and the evolution of foraging behaviour in long ranging greater albatrosses. Oikos 103:374-384

Waugh SM, Weimerskirch H, Cherel Y, Shankar U, Prince PA, Sagar PM (1999) Exploitation of the marine environment by two sympatric albatrosses in the Pacific Southern Ocean. Mar Ecol Prog Ser 177:243-254

Weimerskirch H (1998) Foraging strategies of Indian Ocean albatrosses and their relationships with fisheries. In: Robertson G, Gales R (eds) Albatross biology and conservation. Surrey Beatty \& Sons, Chipping Norton, p 168-179

Weimerskirch H, Guionnet T (2002) Comparative activity pattern during foraging of four albatross species. Ibis 144 : 40-50

Weimerskirch H, Robertson G (1994) Satellite tracking of light-mantled sooty albatrosses. Polar Biol 14:123-126

Weimerskirch H, Wilson RP (1992) When do wandering albatrosses Diomedea exulans forage? Mar Ecol Prog Ser 86: 297-300

Weimerskirch H, Jouventin P, Stahl JC (1986) Comparative 
ecology of the six albatross species breeding on the Crozet Islands. Ibis 128:195-213

Weimerskirch H, Salamolard M, Sarrazin F, Jouventin P (1993) Foraging strategy of wandering albatrosses through the breeding season: a study using satellite telemetry. Auk 110:325-342

Weimerskirch H, Prince PA, Zimmermann L (2000a) Chick provisioning by the yellow-nosed albatross Diomedea chlororhynchos: response of foraging effort to experimentally increased costs and demands. Ibis 142:103-110

Editorial responsibility: Otto Kinne (Editor-in-Chief), Oldendorf/Luhe, Germany
Weimerskirch H, Capdeville D, Duhamel G (2000b) Factors affecting the number and mortality of seabirds attending trawlers and long-liners in the Kerguelen area. Polar Biol 23:236-249

Xavier JC, Rodhouse PG, Trathan PN, Wood AG (1999) A Geographical Information System (GIS) atlas of cephalopod distribution in the Southern Ocean. Antarct Sci 11:61

Xavier JC, Croxall JP, Trathan PN, Wood AG (2003) Feeding strategies and diets of breeding grey-headed and wandering albatrosses at South Georgia. Mar Biol 143:221-232

Submitted: June 8, 2004; Accepted: August 24, 2004

Proofs received from author(s): December 23, 2004 